\title{
PENGARUH BUDAYA ORGANISASI, KEDISIPLINAN DAN MOTIVASI TERHADAP KINERJA PEGAWAI DI RUMAH SAKIT UMUM DAERAH (RSUD) DR. SOEDIRAN MANGUN SUMARSO KABUPATEN WONOGIRI
}

\author{
Iqfan Agfianto $^{1}$, Sri Hartono ${ }^{2}$, Djumali ${ }^{3}$ \\ Universitas Islam Batik Surakarta \\ Email : iqfanagfianto@gmail.com
}

\begin{abstract}
This study has a purpose, namely 1) To know and measure partially the influence of organizational culture, discipline, and motivation on the performance of the RSUD dr. Soediran Mangun Sumarso, Wonogiri Regency. 2) To find out and measure the influence of organizational culture, discipline and motivation on the performance of RSUD dr. Soediran Mangun Sumarso Wonogiri. The population is all employees of RSUD dr. Soediran Mangun Sumarso, Wonogiri Regency, there are a total of 735 employees. The sample in the study was 74 respondents. Methods of collecting data using documentation and questionnaires or questionnaires. Data analysis using classic assumption test, multiple linear test, $t$ test, $f$ test, specified coefficient. Results and conclusions: 1) Partially, there was a significant effect of organizational culture, discipline, and motivation on the performance of RSUD dr. Soediran Mangun Sumarso. 2) There is an influence of organizational culture, discipline and motivation on the performance of RSUD dr. Soediran Mangun Sumarso.
\end{abstract}

Keywords: organizational culture, discipline, motivation, performance

\section{PENDAHULUAN}

Pegawai merupakan aset penting untuk perkembangan suatu perusahaan. Maka suatu perusahaan harus memperhatikan kebutuhan para pegawainya. Pada dasarnya pegawai merupakan roda utama dalam segala aktivitas perusahaan. Perusahaan yang semakin maju akan selalu memikirkan pekerjaan yang efisien dan efektif agar mudah dinilai pelaksanaannya dan dikendalikan sehingga mudah dalam menetapkan kinerja pegawainya.

Kinerja pegawai mencakup kuantitas dan kualitas dalam kecakapan bekerja. Apabila kinerjanya tinggi maka hasilnya juga optimal.

Budaya organisasi yang sudah diterapkan pada suatu organisasi ataupun perusahaan antara satu dengan yang lain berbeda, tetapi mereka memiliki tujuan yang sama untuk memajukan perusahaan atau organisasi yang mereka miliki.

Budaya organisasi bisa memberi dampak pada perkembangan suatu perusahaan. Sama halnya dengan seorang pemimpin diperlukan sikap profesional dan adil dalam pemberian beban kerja.

Kedisiplinan sangat perlu diterapkan. Tindakan disiplin diterapkan oleh perusahaan atau organisasi untuk memberikan efek jera terhadap para pelanggar dari aturan-aturan kerja.

Kedisiplinan muncul ketika ada motivasi untuk mendapatkan prestasi dalam kerja dan faktor peraturan yang harus dijalankan.

Setiap karyawan bekerja memiliki motivasi. Oleh karena itu, pimpinan dituntut dapat memberikan motivasi kepada seluruh karyawan di dalam menjalankan tugasnya. Apabila tertanam semangat yang tinggi tentunya membuat kinerja lebih maksimal. 
Penelitian ini akan mengkaji bagaimana pengaruh budaya organisasi, kedisiplinan dan motivasi terhadap kinerja pegawai Rumah Sakit Umum Daerah (RSUD) dr. Soediran Mangun Sumarso Kabupaten Wonogiri.

\section{LANDASAN TEORI \\ Kinerja}

Kinerja menggambarkan karyawan yang telah mencapai keberhasilan kerja dalam menyelesaikan pekerjaan sesuai dengan tanggung jawab (Hartono, 2015). Menurut Azanita (2016) pegawai yang mempunyai kinerja optimal, harapan tujuan dari suatu perusahaan dapat terwujud dan apabila pegawainya tidak bisa bekerja secara optimal maka tujuan perusahaan akan sulit diraih.

Indikator Kinerja Pegawai, berdasarkan Jackson dan Mathis (2011: 378) indikator kinerja : 1) Kuantitas berdasarkan hasil, 2) Kehadiran, 3) Kualitas berdasarkan dari hasil 4) Kemampuan dalam bekerja sama, 5) Ketepatan waktu dari hasil,

\section{Budaya Organisasi}

Dapat diartikan seperti nilai asumsi atau norma yang sudah disetujui dan diterapkan oleh anggota suatu organisasi untuk dijadikan pemecahan masalah dan dasar perilaku dari sebuah organisasi (Darodjat, 2015: 236).

Indikator Budaya Organisasi menurut Umi, Hamidah dan Ika (2015) ialah : 1) Stabil, 2) Kepedulian pada detail, 3) Mengedepankan tim, 4) Mengedepankan pada manusia, 5) Mengedepankan pada hasil, 6) Inovasi dan keberanian mengambil Risiko 7) Agresif.

\section{Kedisiplinan}

Kedisiplinan (Hasibuan, 2016: 193) ialah seseorang yang sadar dalam hal menaati norma dan aturan perusahaan, prestasi kerja yang tinggi diperoleh apabila disiplin karyawannya baik.

Berdasarkan pendapat Harlie (2010) indikator-indikator disiplin kerja adalah selalu inovatif dan kreatif, tepat waktu dalam bekerja, tidak pernah terlambat, tidak membolos, patuh pada peraturan, memiliki bakat pada bidangnya, motivasi yang tinggi, bersikap yang sopan.

\section{Motivasi}

Motivasi berdasarkan pernyataan Hasibuan (2010) ialah pendorong dalam menumbuhkan semangat, agar dapat bekerja produktif dan tujuan yang telah direncanakan dapat dicapai. Motivasi dinilai sebagai kemauan untuk bersikap semangat dan tidak mudah menyerah (Mulyadi, 2008).

Menurut Harsuko (2011) motivasi kerja dapat diukur melalui indikator : 1). Gaji yang sesuai, 2). Pemberian bonus, 3). Memenuhi kebutuhan konstribusi, 4). Menempatkan karyawan sesuai dengan kemampuan, 5). Memperhatikan lingkungan tempat kerja. 


\section{Kerangka Penelitian}

Untuk mempermudah pemahaman dan memperjelas penelitian maka dapat digambarkan suatu kerangka penelitian teoritis sebagai berikut :

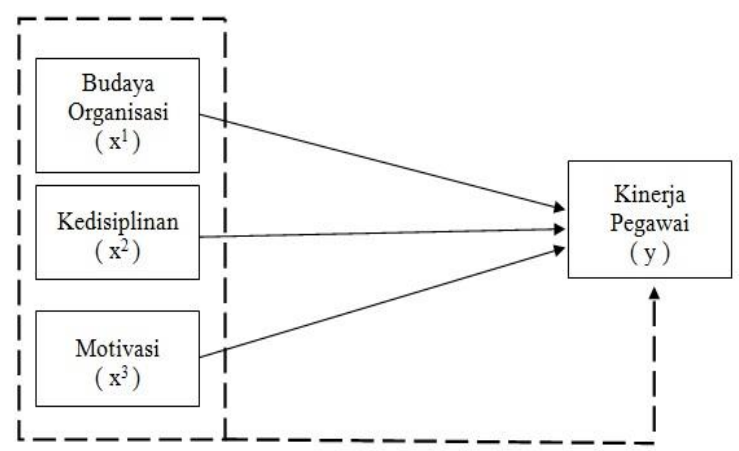

Berdasarkan kerangka pemikiran diatas dapat dilihat bahwa variabel dependentnya yaitu kinerja pegawai. Sedangkan variabel independentnya yaitu budaya organisasi $\left(\mathrm{X}_{1}\right)$, kedisiplinan $\left(\mathrm{X}_{2}\right)$ dan motivasi $\left(\mathrm{X}_{3}\right)$

\section{Hipotesa}

1) Diduga ada pengaruh positif dan signifikan budaya organisasi pada kinerja pegawai RSUD dr. Soediran Mangun Sumarso Kabupaten Wonogiri.

2) Diduga ada pengaruh positif dan signifikan kedisiplinan kerja pada kinerja karyawan RSUD dr. Soediran Mangun Sumarso Kabupaten Wonogiri.

3) Diduga ada pengaruh positif dan signifikan motivasi pada kinerja karyawan RSUD dr. Soediran Mangun Sumarso Kabupaten Wonogiri.

4) Diduga ada pengaruh positif dan signifikan secara simultan budaya organisasi, kedisiplinan dan motivasi pada kinerja pegawai RSUD dr. Soediran Mangun Sumarso Kabupaten Wonogiri.

\section{METODE PENELITIAN}

\section{Populasi dan Sampel}

Populasi penelitian yaitu pegawai RSUD dr. Soediran Mangun Sumarso dengan total populasi ada sebanyak 735 pegawai.

Sampel pada penelitian berjumlah 74 orang. Penelitian ini menggunakan random sampling dalam penentuan sampel.

\section{Tehnik Pengumpulan data}

Pada penelitian ini, peneliti memakai dua metode, yaitu : kuesioner dan studi dokumentasi.

\section{Model dan Teknis Analisis}

Untuk membuktikan dampak budaya organisasi, kedisiplinan dan motivasi terhadap kinerja karyawan RSUD dr. Soediran Mangun Sumarso memakai analisis regresi linear berganda. Berikut bentuk persamaan regresinya :

$Y=\alpha+b_{1} X_{1}+b_{2} X_{2}+b_{3} X_{3}+e$ 
Keterangan :

$\alpha=$ Konstanta

$\mathrm{Y}=$ Kinerja pegawai

bn $=$ Koefisien regresi variabel bebas ke-n

$\mathrm{X}_{1}$ = budaya organisasi

$\mathrm{X}_{2}=$ kedisiplinan

$\mathrm{X}_{3}=$ motivasi

e $=$ Variabel pengganggu

Lalu dilakukan uji t, uji f dan koefisien determinasinya.

\section{Pengujian Hipotesis}

Untuk menguji hipotesis pertama hingga ketiga peneliti menggunakan uji $t$, uji $t$ menggambarkan pengaruh suatu independen kepada variabel dependen dengan dianggap variabel independen yang lain itu konstan. Apabila t hitung $>t$ tabel, dapat dikatakan budaya organisasi, kedisiplin dan motivasi secara simultan ada pengaruh signifikan pada kinerja pegawai atau bisa disebut Ho ditolak dan Ha diterima.

Kemudian uji f, menggambarkan keseluruhan variabel independen apakah yang dimasukan memiliki pengaruh secara simultan kepada variabel dependen. Ha : dapat diterima bila $F$ hitung $>$ F tabel, Sedangkan Ho ditolak.

\section{HASIL DAN PEMBAHASAN}

Perhitungan hasil analisa regresi berganda menggunakan aplikasi SPSS 17 disajikan dalam tabel berikut :

$\mathrm{F}_{\text {hitung }}=24,899$

Tabel 1 Hasil Analisa Regresi Berganda

\begin{tabular}{|c|c|c|c|c|c|c|c|}
\hline & & Mode I & $\begin{array}{r}\text { Unstan } \\
\text { Coeff }\end{array}$ & $\begin{array}{l}\text { Irdized } \\
\text { ients }\end{array}$ & $\begin{array}{c}\text { Standardized } \\
\text { Coefficients }\end{array}$ & & \\
\hline & & & $\mathbf{B}$ & $\begin{array}{c}\text { Std. } \\
\text { Error }\end{array}$ & Beta & $\mathbf{t}$ & Sig. \\
\hline & & (Constant) & 1.475 & 2.194 & & .672 & .504 \\
\hline & & $\begin{array}{l}\text { BUDAYA } \\
\text { ORGANISASI }\end{array}$ & .238 & .117 & .184 & 2.029 & .046 \\
\hline & & KEDISIPLINAN & .249 & .090 & .266 & 2.769 & .007 \\
\hline & & MOTIVASI & .279 & .058 & .458 & 4.797 & .000 \\
\hline & & Dependent Variabl & KINEF & & & & \\
\hline$F_{\text {hitung }}=24,899$ & $\mathrm{n}$ & $=86$ & & & & & \\
\hline $\mathrm{F}_{\text {tabel }}=2,74$ & $\operatorname{sig}$ & $=0,000$ & & & & & \\
\hline $\mathrm{T}_{\text {tabel }}=1,99$ & & & & & & & \\
\hline
\end{tabular}

Sesuai dengan perhitungan analisa regresi linier berganda ialah :

$\mathrm{Y}=1,475+0,238 \mathrm{X}_{1}+0,249 \mathrm{X}_{2}+0,279 \mathrm{X}_{3}+\mathrm{e}$

Hasilnya yaitu ada pengaruh dari budaya organisasi, kedisiplinan dan motivasi pada kinerja pegawai. Sebaliknya dari uji $\mathrm{t}$ didapat variabel budaya organisasi dengan nilai $\mathrm{t}_{\text {hitung }}=2,029>\mathrm{t}$ tabel $=1,99$, sehingga $\mathrm{H}_{\mathrm{o}}$ ditolak maka diperoleh pengaruh yang signifikan budaya organisasi pada kinerja pegawai, kedisiplinan nilai $\mathrm{t}_{\text {hitung }}=2,769>\mathrm{t}_{\text {tabel }}=1,99$, sehingga Ho ditolak maka terdapat pengaruh yang signifikan kedisiplinan pada kinerja pegawai. Dan perhitungannya 
variabel motivasi diperoleh hasil $\mathrm{t}_{\text {hitung }}=4,797>\mathrm{t}_{\text {tabel }}=1,99$, sehingga Ho ditolak maka terdapat pengaruh yang signifikan motivasi pada kinerja pegawai.

Bersumber dari hasil perhitungan uji $\mathrm{F}$ bisa dilihat $\mathrm{F}_{\text {hitung }}=24,899>\mathrm{F}_{\text {tabel }}=2,74$, sehingga Ho ditolak maka didapat secara stimultan terdapat pengaruh yang signifikan budaya organisasi $\left(\mathrm{X}_{1}\right)$, kedisiplinan $\left(\mathrm{X}_{1}\right)$, motivasi $\left(\mathrm{X}_{2}\right)$ terhadap kinerja pegawai.

\section{Pembahasan}

Hasil analisis menggambarkan bahwa variabel budaya organisasi, kedisiplinan maupun motivasi baik itu secara bersama-sama maupun parsial memang ada pengaruh positif dan signifikan pada kinerja karyawan.

\section{KESIMPULAN DAN SARAN}

\section{Kesimpulan}

1) Ada pengaruh yang signifikan budaya organisasi pada kinerja karyawan Rumah Sakit Umum Daerah Wonogiri.

2) Ada pengaruh signifikan kedisiplinan terhadap pada kinerja karyawan Rumah Sakit Umum Daerah Wonogiri.

3) Ada pengaruh signifikan motivasi pada kinerja karyawan Rumah Sakit Umum Daerah Wonogiri.

4) Ada pengaruh budaya organisasi, kedisiplinan dan motivasi pada kinerja karyawan Rumah Sakit Umum Daerah Wonogiri.

\section{Saran}

Berdasarkan analisa dan kesimpulan, maka dapat disampaikan saran-saran, agar lebih ditingkatkan lagi mengenai budaya organisasi pada RSUD dr. Soediran Mangun Sumarso agar kinerja pegawai lebih meningkat dan jauh lebih baik lagi.

\section{REFERENSI}

Andi P., Osman L., Hasanuddin R., 2016. Pengaruh Motivasi, Disiplin Dan Kepuasan Terhadap Kinerja Pegawai Badan Kepegawaian Daerah Provinsi Sulawesi Barat. Indonesian Journal of Business and Management, Vol. 2, No.1 tahun 2016.

Citra A. R., Djumali, Sri Hartono, 2018. Pengaruh Kepemimpinan, Motivasi Kerja, Dan Lingkungan Kerja Terhadap Kinerja Karyawan Di Badan Perencanaan, Penelitian, Dan Pengembangan Daerah Surakarta. Jurnal Ekonomi Dan Kewirausahaan, 18. 